\title{
Transferrin: A Potential Source of Iron for Oxygen Free Radical-Mediated Endothelial Cell Injury
}

\author{
Joan K. Brieland, ${ }^{*, 1}$ Susan J. Clarke, ${ }^{*}$ Soverin Karmiol, $\dagger$ Sem H. Phan, $\dagger$ and Joseph C. Fantone $\dagger$ \\ ${ }^{*}$ Unit for Laboratory Animal Medicine and $†$ Department of Pathology, University of Michigan Medical School, \\ Ann Arbor, Michigan 48109
}

Received September 16, 1991, and in revised form December 13, 1991

The ability of transferrin to potentiate oxygen free radical-mediated endothelial cell injury was assessed. ${ }^{51} \mathrm{Cr}$-labeled endothelial cells derived from rat pulmonary arteries (RPAECs) were incubated with hydrogen peroxide $\left(\mathrm{H}_{2} \mathrm{O}_{2}\right)$ in the presence and absence of holosaturated human transferrin, and the effect of transferrin on $\mathrm{H}_{2} \mathrm{O}_{2}$ mediated endothelial cell toxicity was determined. Addition of holosaturated transferrin potentiated $\mathrm{H}_{2} \mathrm{O}_{2}$ mediated RPAEC cytotoxicity at concentrations of $\mathrm{H}_{2} \mathrm{O}_{2}$ greater than $10 \mu \mathrm{M}$, suggesting that transferrin may provide a source of iron for free radical-mediated endothelial cell injury. Free radical-mediated injury is dependent on non-protein-bound iron. The ability of RPAECs to facilitate the release of iron from transferrin was assessed. We determined that RPAECs facilitate the release of transferrin-derived iron by reduction of transferrinbound ferric iron $\left(\mathrm{Fe}^{3+}\right)$ to ferrous iron $\left(\mathrm{Fe}^{2+}\right)$. The reduction and release of transferrin-derived $\mathrm{Fe}^{2}$ ' were inhibited by apotransferrin and chloroquine, indicating a dependence on receptor-specific binding of transferrin to the RPAEC cell surface, with subsequent endocytosis, acidification, and reduction of transferrin-bound $\mathrm{Fe}^{\mathrm{s}+}$ to $\mathrm{Fe}^{2+}$. The release of transferrin-derived $\mathrm{Fe}^{2+}$ was potentiated by diethyldithiocarbamate, an inhibitor of intracellular superoxide dismutase (SOD). In contrast, exogenous SOD did not alter iron release, suggesting that intracellular superoxide anion $\left(\mathrm{O}_{2}^{-}\right)$may play an important role in mediating the reduction and release of transferrin-derived iron. Results of this study suggest that transferrin may provide a source of iron for oxygen free radical-mediated endothelial cell injury und identify a novel mechanism by which endothelial cells may mediate the reduction and release of transferrin-derived iron. 1992 Academic Press, Inc.

\footnotetext{
${ }^{1}$ To whom all correspondence should be addressed at Unit for Laboratory Animal Medicine, 010 Animal Research Facility, University of Michigan Medical School, 1301 Catherine Road, Ann Arbor, MI 481090614.
}

Free radical-mediated endothelial cell injury is dependent on the presence of ionic iron (1). Iron promotes cell injury by its ability to catalyze hydroxyl radical $\left(\mathrm{OH}^{\circ}\right)$ formation via a Fenton reaction and by peroxidation of unsaturated lipids. Under normal physiological conditions, iron is bound to iron-binding proteins and is unable to participate in biological reactions in this bound state. Transferrin is the primary iron-binding protein in the vertebrate bloodstream. Iron $\left(\mathrm{Fe}^{3+}\right)$ is normally bound to transferrin in a ternary complex involving iron, transferrin, and bicarbonate (2-6). A most challenging question in transferrin chemistry is identification of mechanisms by which transferrin is induced to release iron (7). Reduction of transferrin-bound ferric iron $\left(\mathrm{Fe}^{3+}\right)$ to ferrous iron $\left(\mathrm{Fe}^{2+}\right)$, which binds weakly to transferrin, is one mechanism by which iron is released $(3,4,8)$. The results of previous investigations suggest that both hepatocytes and polymorphonuclear leukocytes (PMNs) ${ }^{2}$ promote the reduction and release of transferrin-derived iron at the cell surface, although by different mechanisms. Hepatocyte plasma membranes have been reported to contain an NADH diferric transferrin reductase which facilitates the transfer of electrons from intracellular NADH to plasma membrane-bound transferrin, resulting in the release of transferrin-derived $\mathrm{Fe}^{2+}(9)$, while $\mathrm{PMNs}$ generate extracellular superoxide anion $\left(\mathrm{O}_{2}{ }^{-}\right)$, which, under acidic conditions, facilitates the reduction and release of transferrin-derived iron (10).

The results of recent investigations suggest that a source of iron for free radical-mediated endothelial cell injury is the endothelial cell itself (1). Endothelial cells have previously been shown to have cell surface receptors for transferrin (11). Theoretically, transferrin-derived

\footnotetext{
${ }^{2}$ Abbreviations used: PMNs, polymorphonuclear leukocytes; RPAECs, rat pulmonary artery endothelial cells; FBS, fetal bovine serum; HBSS, Hanks' balanced salt solution; BPS, bathophen anthroline disulfonic acid; NTA, nitrilotriacetic acid; PBS, phosphate-buffered saline; BSA, bovine serum albumin; TD buffer, Tris-salt buffer; SOD, superoxide dismutase; $\mathrm{XO}$, xanthine oxidase; $\mathrm{DDC}$, diethyldithiocarbamate.
} 
iron could potentiate free radical-mediated endothelial cell toxicity. The ability of endothelial cells to mediate the release of iron from transferrin has not been thoroughly investigated. In the following investigation, the effect of transferrin on oxygen free radical-mediated endothelial cell cytotoxicity was assessed. The ability of endothelial cells to facilitate the release of iron from transferrin was also studied. A novel mechanism by which endothelial cells may mediate the reduction and release of transferrin-derived iron, thereby providing a source of non-protein-bound iron for oxidant-mediated endothelial cell injury, was identified.

\section{MATERIALS AND METHODS}

Chemicals. All chemicals were obtained from Sigma Chemical Company (St. Louis, MO) unless otherwise noted.

Endothelial cells. Endothelial cells from rat pulmonary arteries (RPAECs) (the generous gift of Dr. James Varani and Dr. Sem Phan, University of Michigan Medical School, Ann Arbor) were obtained as previously described (12). RPAECs were used between passages 24 and 31. Cells were maintained in monolayer cultures in DMEM-F12 supplemented with $10 \%$ fetal bovine serum (FBS), 2 mM glutamine, and $100 \mathrm{U} / \mathrm{ml}$ penicillin, streptomycin, and fungizone. Cells were passaged by mechanical scraping without exposure to proteases. Growth was at $37^{\circ} \mathrm{C}$ and $5 \% \mathrm{CO}_{2}$. Stocks were kept frozen in liquid nitrogen. Unless otherwise described, for studies using intact RPAECs, cells were subcultured in 35-mm 6-well culture dishes (Costar) in DMEM-F12 with $0.8 \% \mathrm{FBS}, 2 \mathrm{mM}$ glutamine, and $100 \mathrm{U} / \mathrm{ml}$ of penicillin, streptomycin, and fungizone at $1300 \mathrm{cells} / \mathrm{cm}^{2}$. Cells were grown to confluent monolayers (7-9 days). For collection of endothelial cell plasma membranes, endothelial cells were plated at the same density and medium in T150 culture flasks and grown to confluence as described above.

Cytotoxicity assay. Cytotoxicity was measured using a ${ }^{51} \mathrm{Cr}$-release assay as previously described $(1,13)$. Briefly, RPAECs $\left(3.3 \times 10^{5}\right.$ cells/ $\mathrm{ml}$ ) were added to wells of a 24-well culture dish in $1 \mathrm{ml}$ of culture medium containing $2 \mu \mathrm{Ci}$ of $\mathrm{Na}^{51} \mathrm{CrO}_{4}$. RPAECs were incubated overnight $\left(37^{\circ} \mathrm{C}, 5 \% \mathrm{CO}_{2}\right)$ and washed three times with Hanks' balanced salt solution (HBSS), pH 7.4, to remove unincorporated radioactivity. Appropriate reactants $\left[\mathrm{H}_{2} \mathrm{O}_{2}(0-50 \mu \mathrm{M}) \pm\right.$ holosaturated human transferrin $(60 \mu \mathrm{M})]$ were added to wells in a final volume of $1 \mathrm{ml}$ of HBSS per well. After incubation at $37^{\circ} \mathrm{C}$ for $4 \mathrm{~h}$, the culture supernatant was removed from each well and centrifuged $\left(300 \mathrm{~g}, 10 \mathrm{~min}, 4^{\circ} \mathrm{C}\right)$, and 0.5 $\mathrm{ml}$ was assayed to determine ${ }^{51} \mathrm{Cr}$ release (Tm Analytic, Elk Grove Village, IL). Spontaneous release of ${ }^{51} \mathrm{Cr}$ from endothelial cells was determined from wells incubated with HBSS in the absence of additional reactants. Total ${ }^{51} \mathrm{Cr}$ release was determined from wells incubated in $0.1 \%$ Triton $\mathrm{X}-100$. Cytotoxicity was calculated from the percentage of specific ${ }^{51} \mathrm{Cr}$ release by the formula

$$
\% \text { cytotoxicity }=\frac{\text { experimental release }- \text { spontaneous release }}{\text { total release }- \text { spontaneous release }} \times 100 \text {. }
$$

In selected experiments, holosaturated human transferrin was initially dialyzed against $0.1 \mathrm{M}$ sodium perchlorate $\left(\mathrm{NaClO}_{4}\right)$ as described previously (14) to remove any contaminating iron and dialyzed against HBSS prior to use.

Release of $\mathrm{Fe}^{2+}$ from holosaturated human transferrin. The reduction of diferric transferrin by RPAECs was measured by the formation of the ferrous bathophenanthroline disulfonate $\left(\mathrm{Fe}^{2+} \cdot \mathrm{BPS}\right.$ ) complex (3). Briefly, confluent RPAEC monolayers in 6-well plates were incubated in $1 \mathrm{ml}$ of HBSS ( $\mathrm{pH} 7.4$ ) containing holosaturated human transferrin $(0-60 \mu \mathrm{M})$ and BPS $(0.50 \mathrm{mM})$, an extracellular $\mathrm{Fe}^{2+}$ chelator (14), for one $1 \mathrm{~h}$ at $37^{\circ} \mathrm{C}$. The reduction and release of transferrin-derived $\mathrm{Fe}^{2+}$ were determined spectrophotometrically by the change in absorbance (AU) at $535 \mathrm{~nm}$ of RPAEC-conditioned medium using a Cary 210 spectrophotometer (Varion, Inc., Palo Alto, CA). The lower limit of AU change that can be measured accurately under conditions in these experiments is 0.001 . The change in absorbance of RPAEC-conditioned medium divided by the extinction coefficient of the $\mathrm{Fe}^{2+}$. BPS complex $\left(2.214 \times 10^{4} \mathrm{M}^{-1} \mathrm{~cm}^{-1}\right)$ yields nanomoles of $\mathrm{Fe}^{2+}$ released from diferric transferrin. Results are expressed as nanomoles of $\mathrm{Fe}^{2+}$ released $/ 10^{6}$ RPAECs $/ 60 \mathrm{~min}$. In selected experiments, the effect of specific inhibitors on RPAEC-mediated release of transferrin-derived $\mathrm{Fe}^{2+}$ was determined. For these experiments, RPAECs were preincubated with the inhibitors $\left(37^{\circ} \mathrm{C}\right)$ prior to addition of transferrin $(60 \mu \mathrm{M})$ and BPS $(0.50 \mathrm{mM})$. The concentration of specific inhibitors used and the duration of the preincubation were as follows: apotransferrin $(60 \mu \mathrm{M}, 20 \mathrm{~min})$, superoxide dismutase (30 U/ml, $10 \mathrm{~min})$, adriamycin $\left(10^{-6} \mathrm{M}, 20 \mathrm{~min}\right)$, diethyldithiocarbamate $(0.1 \mathrm{mM}, 20 \mathrm{~min})$, oxypurinol ( $1 \mathrm{mM}, 45 \mathrm{~min})$, rotenone $(0.050 \mathrm{mM}, 20 \mathrm{~min})$, and chloroquine $(1 \mathrm{mM}, 20 \mathrm{~min})$. The dosage and time of incubation were chosen based on previous studies demonstrating effectiveness of the compounds in endothelial cells or other cellular systems $(9,10,15-23)$.

Preparation of transferrin at physiological levels of iron saturation. Transferrin, at physiological levels of iron saturation (i.e., 30$60 \%$ ), was made according to previously published methods $(10,23)$ with minor modifications. A $0.2 \mathrm{mM} \mathrm{Fe} \mathrm{s}^{3+}$ stock solution was prepared by reacting $\mathrm{Fe}^{3+}$ with nitrilotriacetic acid (NTA) at a ratio of $1: 4$ (23). Sideroferrin ( $60 \mu \mathrm{M}$ final) in $0.01 \mathrm{M}$ Tris buffer ( $\mathrm{pH} 7.4$ ) was incubated with Fe - NTA $(0.040-0.072 \mathrm{mM}$ final) in the presence of sodium bicarbonate $\left(\mathrm{NaHCO}_{3}, 10 \mathrm{mM}\right.$ final) for $30 \mathrm{~min}$ at $22^{\circ} \mathrm{C}$. The percentage iron saturation of transferrin was determined by comparison of the change in absorbance at $470 \mathrm{~nm}$ of the solution to that of holosaturated transferrin $(60 \mu \mathrm{M})$. The partially iron-saturated transferrin was dialyzed in PBS (pH 7.4) containing $\mathrm{NaClO}_{4}$ for $24 \mathrm{~h}$ to chelate any extraneous iron (14). The transferrin solution containing $\mathrm{NaClO}_{4}$ was dialyzed against PBS for $12 \mathrm{~h}$, concentrated in an Amicon concentrator, and dialyzed against HBSS (pH 7.4) for $12 \mathrm{~h}$. The protein content of the partially iron-saturated transferrin was assessed via the Bradford protein assay with bovine serum albumin (BSA) as a standard (24). Partially iron-saturated transferrin was then utilized in assays previously described for holosaturated human transferrin.

Purification of $R P A E C$ plasma membranes. Plasma membranes were isolated from intact RPAECs on Cytodex-1 microcarrier beads (25). Cultured RPAECs were removed from T150 flasks hy mechanical scraping. The cells and microcarrier beads were washed three times in attachment buffer consisting of $7 \mathrm{vol}$ of $310 \mathrm{mM}$ sucrose and $3 \mathrm{vol}$ of a $310 \mathrm{mOsm}$ solution of sodium acetate (pH 5.2). The beads and cells were then combined in $20 \mathrm{ml}$ of attachment buffer and incubated together for $15 \mathrm{~min}$ on ice. The microcarrier beads, with adherent endothelial cells, were centrifuged $\left(400 \mathrm{~g}, 10 \mathrm{~min}, 4^{\circ} \mathrm{C}\right)$ and the supernatant was discarded. Adherent cells were then lysed by incubating the microcarrier beads with $0.1 \mathrm{~N} \mathrm{NaOH}$ (pH 8.0). The beads, with adherent RPAEC plasma membranes, were centrifuged $\left(400 \mathrm{~g}, 10 \mathrm{~min}, 4^{\circ} \mathrm{C}\right)$ and the supernatant was discarded. RPAEC plasma membranes were stripped from Cytodex- 1 beads by incubation of microcarrier beads in $0.2 \mathrm{M}$ borate buffer and $0.2 \mathrm{M} \mathrm{NaCl}$ (pH 9.8) for $10 \mathrm{~min}$. The sample was centrifuged $\left(400 \mathrm{~g}, 10 \mathrm{~min}, 4^{\circ} \mathrm{C}\right)$ and the microcarrier beads were discarded. The supernatant containing RPAEC plasma membranes was concentrated over an Amicon PM-10 filter. Protein content of concentrated RPAEC plasma membranes was determined using the Bradford protein assay with bovine serum albumin as a standard (24).

$N A D H$ diferric transferrin reductase activity in RPAEC plasma membranes. NADH diferric transferrin reductase activity in RPAEC plasma membranes was assayed by measuring the formation of $\mathrm{Fe}^{2+} \cdot \mathrm{BPS}$ and the oxidation of NADH in the presence of diferric transferrin (26). The reduction of transferrin-derived iron by isolated plasma membranes was determined by formation of the $\mathrm{Fe}^{2+}$. BPS complex following incubation of RPAEC plasma membranes with transferrin and NADH $(3,27)$. 


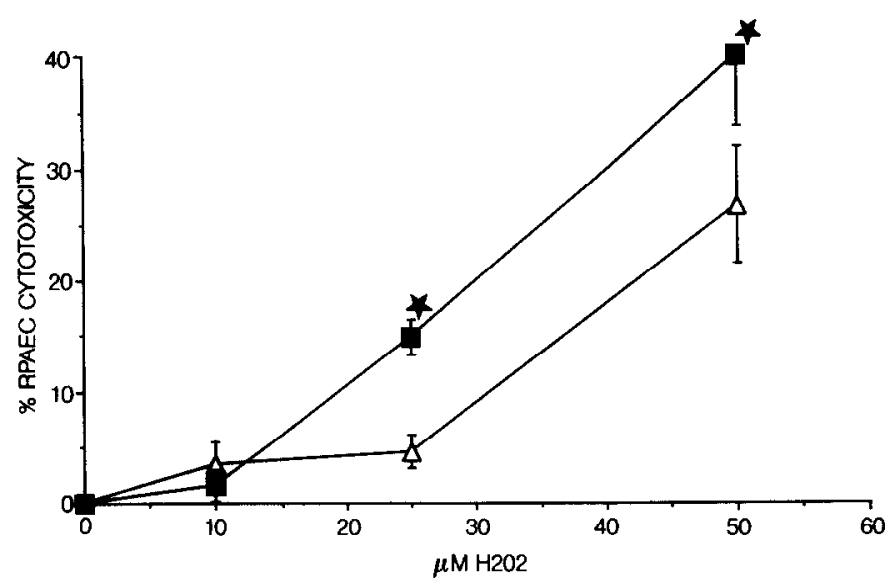

FIG. 1. Effect of transferrin on $\mathrm{H}_{2} \mathrm{O}_{2}$-mediated RPAEC cytotoxicity. ${ }^{51} \mathrm{Cr}$-labeled RPAECs $\left(3.3 \times 10^{5}\right)$ were incubated with $\mathrm{H}_{2} \mathrm{O}_{2}(0-50 \mu \mathrm{M})$ in the absence or presence of holosaturated human transferrin $(60 \mu \mathrm{M})$ for $4 \mathrm{~h}$ at $37^{\circ} \mathrm{C}$. The effect of transferrin on $\mathrm{H}_{2} \mathrm{O}_{2}$-mediated RPAEC cytotoxicity was determined. $\triangle, \mathrm{H}_{2} \mathrm{O}_{2} ; \mathbf{\square}, \mathrm{H}_{2} \mathrm{O}_{2}+$ transferrin. ${ }^{*}$ Significantly different than $\mathrm{H}_{2} \mathrm{O}_{2}$ alone $(P<0.05)$.

Briefly, RPAEC plasma membranes $(0.030 \mathrm{mg}$ protein) were incubated in a final volume of $2.8 \mathrm{ml}$ in Tris-salt (TD) buffer ( $25 \mathrm{mM}$ Trizma base, $140 \mathrm{mM} \mathrm{NaCl}, 5 \mathrm{mM} \mathrm{KCl}, 0.6 \mathrm{mM} \mathrm{Na} 2 \mathrm{PO}_{4}, \mathrm{pH} 7.4$ ) containing BPS (10 $\mu \mathrm{M})$ and NADH $(25 \mu \mathrm{M})$ and the change in absorbance of the sample was recorded using a dual-beam spectrophotometer $(535 \mathrm{~nm}-600 \mathrm{~nm})$. Holosaturated human diferric transferrin $(10 \mu \mathrm{M})$ was added to the reaction and the change in $\mathrm{AU}$ of the sample was determined. The change in $\mathrm{AU}$ following addition of transferrin minus the change in $\mathrm{AU}$ in the absence of transferrin, divided by the extinction coefficient $(17.6$ $\mathrm{mM}^{-1} \mathrm{~cm}^{-1}$ ), yields nanomoles of $\mathrm{Fe}^{2+}$ released from transferrin per minute per milligram of RPAEC plasma membrane. Transferrin-dependent oxidation of NADH by RPAEC plasma membranes was monitored spectrophotometrically in a dual-beam spectrophotometer at $340 \mathrm{~nm}-$ $430 \mathrm{~nm}$. RPAEC plasma membranes $(0.030 \mathrm{mg})$ in a final volume of 2.8 $\mathrm{ml}$ were incubated in $0.05 \mathrm{mM}$ sodium phosphate buffer ( $\mathrm{pH} 7.4$ ) containing $1 \mathrm{mM} \mathrm{KCN}$ and $25 \mu \mathrm{M} \mathrm{NADH}$ and the change in absorbance of the sample was assessed. Holosaturated human transferrin $(10 \mu \mathrm{M})$ was then added to the reaction and the oxidation of NADH monitored spectrophotometrically as described above. The change in AU of the sample in the presence of transferrin minus the change in $\mathrm{AU}$ in the absence of transferrin, divided by the extinction coefficient $\left(6.22 \mathrm{mM}^{-1} \mathrm{~cm}^{-1}\right)$, yields nanomoles of NADH oxidized per minute per milligram of RPAEC plasma membrane.

Statistical analysis. All data represent the means \pm SEM for at least three experiments. Student's paired $t$ test was used to compare differences between treatment groups. $P<0.05$ was considered significant.

\section{RESULTS}

The ability of transferrin to potentiate oxidant-mediated endothelial cell injury was determined (Fig. 1). In agreement with previous reports (13) the addition of $\mathrm{H}_{2} \mathrm{O}_{2}$ to RPAEC cultures potentiated endothelial cell toxicity in a dose-dependent manner. Addition of holosaturated human transferrin $(60 \mu \mathrm{M})$ significantly enhanced $\mathrm{H}_{2} \mathrm{O}_{2}$ mediated RPAEC cytotoxicity at concentrations of $\mathrm{H}_{2} \mathrm{O}_{2}$ greater than $10 \mu \mathrm{M}$ (Fig. 1). Dialysis of holosaturated human transferrin in $0.1 \mathrm{M} \mathrm{NaClO}_{4}$ prior to use did not significantly alter this effect of transferrin on $\mathrm{H}_{2} \mathrm{O}_{2}$-me-

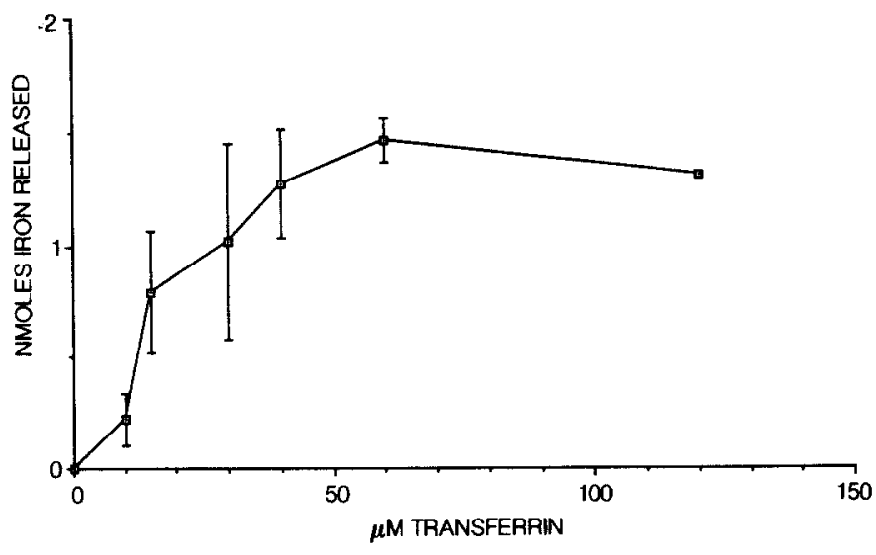

FIG. 2. Effect of transferrin concentration on the reduction and release of transferrin-derived $\mathrm{Fe}^{2+}$ by RPAECs. RPAECs were incubated with holosaturated human transferrin $(0-120 \mu \mathrm{M})$ and the effect of transferrin concentration on the release of transferrin-derived $\mathrm{Fe}^{2+}$ was determined.

diated RPAEC injury (data not shown). These results indicate that holosaturated human transferrin potentiates oxygen free radical-mediated endothelial cell cytotoxicity.

Protein-bound iron is not able to facilitate free radicalmediated injury. However, incubation of intact RPAECs with holosaturated transferrin resulted in the reduction and release of transferrin-derived $\mathrm{Fe}^{2+}$ (Fig. 2). The amount of $\mathrm{Fe}^{2+}$ released was proportional to the concentration of transferrin in the reaction (Fig. 2) and to the duration of incubation of intact RPAECs with transferrin (Fig. 3). Maximum $\mathrm{Fe}^{2+}$ release was observed at $0.060 \mathrm{mM}$ transferrin (Fig. 2) and occurred only after a $30-\mathrm{min}$ latent period, rapidly approaching a maximum at $60 \mathrm{~min}$ (Fig. 3).

Intravascular transferrin is normally only partially iron saturated (28). Therefore, the ability of RPAECs to fa-

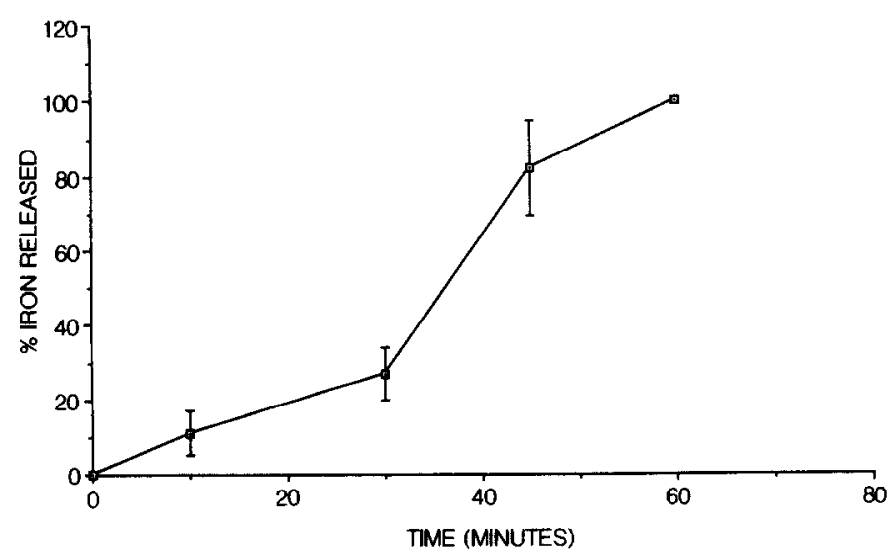

FIG. 3. Effect of duration of incubation on the reduction and release of transferrin-derived $\mathrm{Fe}^{2+}$ by RPAECs. RPAECs $\left(10^{6}\right)$ were incubated with holosaturated human transferrin $(60 \mu \mathrm{M})$ for $0-60 \mathrm{~min}$ and the effect of duration of incubation of transferrin with RPAECs on the release of transferrin-derived $\mathrm{Fe}^{2+}$ was determined. Results are expressed as percentage iron released compared with nanomoles of $\mathrm{Fe}^{2+}$ released/ $10^{6} \mathrm{RPAECs} / 60 \mathrm{~min}$. 
cilitate the reduction and release of iron from partially iron-saturated (30-60\%) transferrin was assessed. Results of these investigations (data not shown) indicate that RPAECs are unable to promote the release of detectable amounts of iron from partially $(<60 \%)$ iron-saturated transferrin. In subsequent experiments, the mechanism by which RPAECS facilitate the release of iron from holosaturated transferrin was investigated. The release of transferrin-derived iron by other cells, including hepatocytes and HeLa cells, has previously been shown to be dependent on transferrin binding to cell surface receptors $(9,18)$. Endothelial cells also have cell surface receptors for transferrin (11). To determine if the release of transferrin-derived $\mathrm{Fe}^{2+}$ by RPAECs was dependent on transferrin binding to cell surface receptors, intact RPAECs were preincubated with apotransferrin (Fig. 4) and the effect on the release of transferrin-derived iron was assessed. Preincubation of RPAECs with apotransferrin inhibited the release of transferrin-derived $\mathrm{Fe}^{2+}$ by $95 \%$ $(P<0.02)$. These results indicate that the release of $\mathrm{Fe}^{2+}$ from holosaturated human transferrin by intact RPAECs is dependent, at least in part, on transferrin binding to transferrin receptors on the RPAEC cell surface.

Previous studies indicate that the reduction and release of transferrin-derived $\mathrm{Fe}^{2+}$ by liver cells and HeLa cells (9) is due to a cell membrane-associated NADH diferric transferrin reductase. This enzyme functions as a transmembrane electron transport, transferring electrons from intracellular NADH to transferrin bound iron, generating $\mathrm{Fe}^{2+}(9)$. To determine if a similar electron transport system exists in RPAECs, RPAEC plasma membranes were purified and assessed for the presence of NADH diferric transferrin reductase activity (see Materials and Methods). Neither the release of transferrin-derived $\mathrm{Fe}^{2+}$ nor the transferrin-dependent oxidation of $\mathrm{NADH}$ by isolated RPAEC plasma membranes (data not shown) was detected. Furthermore, incubation of intact RPAECs with adriamycin, an inhibitor of NADH diferric transferrin reductase activity in HeLa cells and hepatocyte plasma membranes (16), failed to inhibit the reduction and release of transferrin-derived iron (Fig. 4). These results indicate that RPAEC plasma membranes lack NADH diferric transferrin reductase activity, suggesting that RPAECs mediate the reduction and release of transferrin-derived iron by an alternative mechanism.

Alternatively, phagocytic cells, including human PMNs, generate extracellular superoxide anion $\left(\mathrm{O}_{2}^{-}\right)$, which, under acidic conditions, has been shown to reduce transferrin-bound $\mathrm{Fe}^{3+}$ to $\mathrm{Fe}^{2+}(10)$. The reduction and release of transferrin-derived iron by PMNs are inhibited by incubation of PMNs with superoxide dismutase (SOD) (10). Endothelial cells have previously been shown to produce $\mathrm{O}_{2}^{-}(25,26)$. To determine if RPAEC-derived extracellular $\mathrm{O}_{2}^{-}$facilitates the reduction and release of transferrinderived iron, the amount of extracellular $\mathrm{O}_{2}^{-}$generated by RPAECs was determined. Results of these experiments

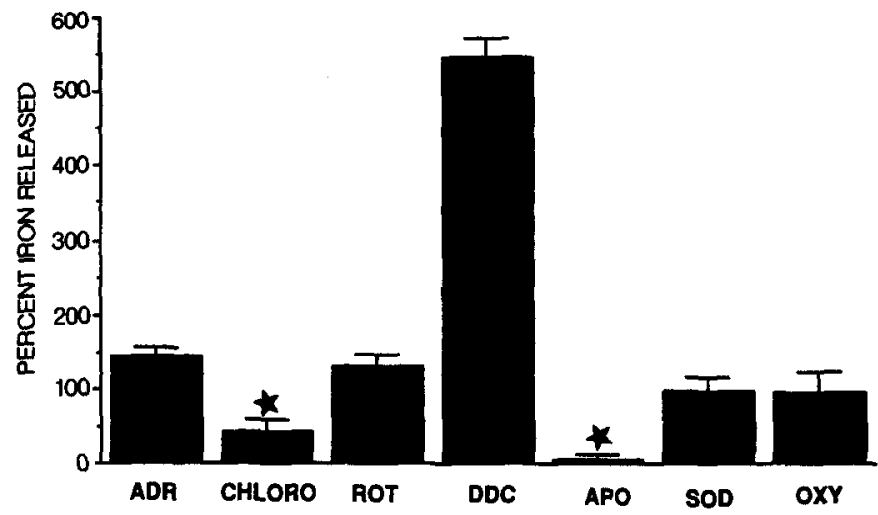

FIG. 4. Effect of inhibitors on the reduction and release of transferrinderived iron by RPAECs. RPAECs were preincubated with inhibitors [apotransferrin (APO), $60 \mu \mathrm{M}, 20 \mathrm{~min}$; superoxide dismutase (SOD), 30 $\mathrm{U} / \mathrm{ml}, 10 \mathrm{~min}$; adriamycin (ADR), $10^{-8} \mathrm{M}, 20 \mathrm{~min}$; diethyldithiocarbamate (DDC), $0.1 \mathrm{mM}, 20 \mathrm{~min}$; oxypurinol (OXY), $1 \mathrm{mM}, 45 \mathrm{~min}$; rotenone (ROT), $0.050 \mathrm{mM}, 20 \mathrm{~min}$; and chloroquine, (CHLORO), $1 \mathrm{mM}, 20 \mathrm{~min}$ ] and the effect of the inhibitors on the reduction and release of transferrinderived iron was determined. Results are expressed as percentage $\mathrm{Fe}^{2+}$ released compared with nanomoles of $\mathrm{Fe}^{2+}$ released $/ 10^{6} \mathrm{RPAECs} / 60$ $\min$ in the absence of inhibitors. "Significantly less than control $(P<$ 0.05).

indicate that $10^{6}$ RPAECs spontaneously generate approximately $0.6 \mathrm{nmol}$ extracellular $\mathrm{O}_{2}^{-} / \mathrm{h}$. In subsequent experiments, RPAECs were preincubated with SOD and the effect of SOD on the reduction of diferric transferrin was determined (Fig. 4). Incubation of RPAECs with SOD did not inhibit the release of transferrin-derived $\mathrm{Fe}^{2+}$, indicating that the release of transferrin-derived iron by RPAECs is not mediated by extracellular $\mathrm{O}_{2}^{-}$.

Many cells, including endothelial cells, also generate $\mathrm{O}_{2}^{-}$intracellularly, due to production of oxygen radicals by subcellular components including mitochondria (3033 ), endoplasmic reticulum (32), and cytoplasmic enzymes including xanthine oxidase (XO) $(29,34)$. Theoretically, the reduction of transferrin-derived iron by RPAECs could be mediated by intracellular $\mathrm{O}_{2}^{-}$. To determine if intracellular $\mathrm{O}_{2}^{-}$facilitates the reduction and release of transferrin-derived $\mathrm{Fe}^{2+}$, RPAECs were incubated with diethyldithiocarbamate (DDC), a potent inhibitor of the cytoplasmic $\mathrm{Cu}-\mathrm{Zn}$ superoxide dismutase (CuZn-SOD, $[35,36])$. As shown in Fig. 4, incubation of RPAECs with DDC enhanced the release of transferrin-derived $\mathrm{Fe}^{2+}$ greater than fivefold. Because DDC has previously been shown to be a modestly good reducing agent (37), the ability of DDC to facilitate the reduction of iron bound to transferrin in the absence of cells was determined. Results of these experiments indicate that DDC $(0.1 \mathrm{mM})$ does facilitate the release of relatively small amounts of $\mathrm{Fe}^{2+}$ from transferrin $\left(0.22 \mathrm{nmol} \mathrm{Fe}{ }^{2+} / 0.060 \mathrm{mM}\right.$ transferrin/h). However, approximately 35 -fold more $\mathrm{Fe}^{2+}$ is released when RPAECs that have been preincubated with DDC are incubated with transferrin (Fig. 4). These results suggest that the reduction and release of transferrin-de- 
rived iron by RPAECs are mediated, at least in part, by intracellular $\mathrm{O}_{2}^{-}$.

While several subcellular components can generate oxygen free radicals, results of recent reports indicate that a significant amount of free radical generation by endothelial cells is due to XO activity $(20,27)$. To determine the role of endothelial cell-derived $\mathrm{XO}$ in the release of transferrin-derived $\mathrm{Fe}^{2+}$, RPAECs were incubated with oxypurinol [a potent inhibitor of XO (20)] and the effect on the release of transferrin-derived $\mathrm{Fe}^{2+}$ was determined (Fig. 4). Incubation of RPAECs with oxypurinol, at concentrations previously shown to inhibit RPAEC XO activity (20), failed to significantly inhibit the reduction and release of iron from transferrin indicating that XO is an unlikely source of intracellular $\mathrm{O}_{2}^{-}$for reduction of diferric transferrin. Mitochondrial respiratory chain components also generate $\mathrm{O}_{2}^{-}$, due to the formation of semiquinones, which spontaneously oxidize producing intramitochondrial $\mathrm{O}_{2}^{-}(21)$. To assess the possible role of mitochondria-derived $\mathrm{O}_{2}^{-}$in the reduction of transferrin-bound iron, RPAECs were incubated with rotenone which inhibits the mitochondrial respiratory chain and induces maximal rates of $\mathrm{O}_{2}^{-}$generation (21). Incubation of RPAECs with rotenone did not significantly enhance the release of transferrin-derived $\mathrm{Fe}^{2+}$ by RPAECs (Fig. 4). Furthermore, it has previously been shown that $\mathrm{O}_{2}^{-}$ does not efficiently permeate the phospholipid bilayer of intact mitochondria (21). Therefore, the reduction of transferrin-derived iron by RPAECs is not likely to be mediated by mitochondria-derived $\mathrm{O}_{2}^{-}$.

The uptake of iron by mammalian cells involves receptor-mediated endocytosis and internalization of the transferrin-transferrin receptor complex (38), followed by labilization of transferrin-bound iron in an intracellular acidic vesicle. Acidification of transferrin potentiates the labilization of its iron, due to hydrogen ion-induced changes in the conformation of the $\mathrm{Fe}^{3+}$-transferrin - bicarbonate complex. These conformational changes in transferrin result in a decreased binding affinity of transferrin for iron $(2,22,39,40)$ and increased susceptibility of the iron to reduction. To determine the potential role of endocytosis and acidification on the release of transferrin-derived $\mathrm{Fe}^{2+}$, RPAECs were preincubated with chloroquine, which both affects uptake of extracellular ligands to endosomes $(41,42)$ and increases the intracytoplasmic $\mathrm{pH}(16,43-45)$. Incubation of RPAECs with chloroquine significantly inhibits the release of transferrin-derived $\mathrm{Fe}^{2+}$ (Fig. 4), indicating an important role of endocytosis and vesicle acidification in the labilization of transferrin-derived iron by RPAECs.

\section{DISCUSSION}

Previous investigations have suggested that iron derived from endothelial cells is critical for oxygen free radicalmediated endothelial cell injury (1). Results of this study indicate that transferrin potentiates oxygen free radicalmediated endothelial cell cytotoxicity. Furthermore, RPAECs promote the release of detectable amounts of iron from holosaturated but not from partially iron saturated human transferrin. The inability of RPAECs to promote the release of detectable amounts of iron from partially iron saturated transferrin may be due, at least in part, to the differences in binding affinity of the two transferrin iron binding sites, resulting in enhanced affinity of partially iron-saturated transferrin for iron relative to holosaturated transferrin (46). The mechanism by which RPAECs potentiate the reduction and release of transferrin-derived iron was investigated. Results of these experiments indicate that the release of transferrinderived iron by RPAECs is dependent on transferrin binding, followed by endocytosis and acidification of transferrin, because apotransferrin and chloroquine respectively inhibited the reaction. Incubation of RPAECs with DDC potentiated the reduction and release of iron from transferrin, suggesting that endocytosed transferrin is reduced by intracellular $\mathrm{O}_{2}^{-}$, resulting in the release of $\mathrm{Fe}^{2+}$. Although xanthine oxidase (XO) has previously been identified as an intracellular source of $\mathrm{O}_{2}^{-}$in endothelial cells $(20,27)$, incubation of RPAECs with oxypurinol failed to significantly inhibit the release of iron from transferrin. These results suggest that alternative sources of intracellular $\mathrm{O}_{2}^{-}$, which mediate the release of transferrin-derived $\mathrm{Fe}^{2+}$, must be examined. The existence of additional pathways for intracellular $\mathrm{O}_{2}^{-}$production in endothelial cells is supported by previous reports which show that incubation of endothelial cells with oxypurinol fails to totally inhibit $\mathrm{O}_{2}^{-}$production (27).

In summary, a possible sequence of events resulting in oxygen free radical-mediated endothelial cell injury in vivo identified by these in vitro experiments is as follows. At an inflammatory focus there is destruction of the endothelial barrier resulting in the extravasation of serum proteins, including transferrin, red blood cells, and leukocytes into the inflammatory site. While intravascular transferrin is normally only partially iron saturated (28), it has previously been shown that, where there is significant hemorrhage, the iron binding capacity of extravascular transferrin can approach $100 \%$ (47). Holosaturated human transferrin, present at the inflammatory focus, binds to transferrin receptors on the endothelial cell surface and is endocytosed into acidic endosomes in the endothelial cell. Within the endosomes, transferrin-bound ferric iron is labilized (due to the acidity of the endosomal environment) and is therefore more susceptible to reduction. The labilized, transferrin-derived iron is subsequently reduced to $\mathrm{Fe}^{2+}$ by $\mathrm{O}_{2}^{-}$generated intracellularly in RPAECs by an as of yet unidentified mechanism. Subsequent reaction of the reduced non-protein-bound iron with hydrogen peroxide and lipid hydroperoxides generated by activated phagocytes at the inflammatory focus 
could result in the generation of reactive hydroxyl $\left(\mathrm{OH}^{*}\right)$ and lipid radicals and subsequent free radical-mediated endothelial cell toxicity.

\section{ACKNOWLEDGMENTS}

This research was supported in part by American Heart of Michigan Grant $901 \mathrm{G} 03$ and by National Institutes of Health Grants RR-07008, RR-00200, HL-44085, and HL-28737.

\section{REFERENCES}

1. Gannon, D. E., Varani, J., Phan, S. H., Ward, J. H., Kaplan, J., Till, G. O., Simon, R. H., Ryan, U. J., and Ward, P. A. (1987) Lab. Invest. 57, 37-44.

2. Carver, F., and Frieden, E. (1978) Biochemistry 17, 167-172.

3. Kojima, N., and Bates, G. (1979) J. Biol. Chem. 254, 8847-8854.

4. Harris, D., Rinehart, A., Hereld, D., Schwartz, R., Burke, F., and Salvador, A. (1985) Biochim. Biophys. Acta 838, 295-301.

5. Hubers, H., and Finch, C. (1987) Physiol. Rev. 67, 520-528.

6. Morgan, E. (1979) Biochim. Biophys. Acta 580, 312-326.

7. Braughler, J., Duncan, L., and Chase, R. (1986) J. Biol. Chem. 261, 10282-10289.

8. Gaber, B., and Aisen, P. (1970) Bivchim. Biophys. Acta 221, 228233.

9. Low, H., Sun, I. L., Navas, P., Grebling, C., Crane, F. L., and Morre, D. J. (1986) Biochim. Biophys. Res. Commun. 139, 1117-1123.

10. Brieland, J., and Fantone, J. C. (1991) Arch. Biochem. Biophys. 284, 78-83.

11. Fishman, J. B., Rubin, J. B., Handrahan, J. V., Connor, J. R., and Fine, R. E. (1987) J. Neurosci. Res. 18, 299-304.

12. Ryan, U. S., Clements, E., Habliston, D., and Ryan, J. W. (1978) Tissue Cell. 10, 535-554.

13. Varani, J., Ginsburg, I., Schuger, L., Gibbs, D. F., Bromberg, J., Johnson, K. J., Ryan, U. S., and Ward, P. A. (1989) Am. J. Pathol. 135, 435-438.

14. Baldwin, D., Jenny, E., and Aisen, P. (1984) J. Biol. Chem. 259, 13391-13394.

15. Thorstensen, K., and Romslo, I. (1984) Biochim. Biophys. Acta 804, 200-208.

16. Poole, B., and Okhuma, S. (1981) J. Cell. Biol. 90, 665-669.

17. Sun, I. L., Navas, P., Crane, F. L., Morre, D. J., and Low, H. (1987) Biochem. Int. 14, 119-127.

18. Toole-Simms, W., Sun, I. L., Morre, D. J., and Crane, F. L. (1990) Biochem. Int. 21, 761-769.

19. Sun, I. L., Garcia-Canero, R., Liu, W., Toole-Simms, W., Crane, F. L., Morre, D. J., and Low, H. (1987) Biochem. Biophys. Res. Commun. 145, 467-473.

20. Phan, S. H., Gannon, D. E., Varani, J., Ryan, U. S., and Ward, P. A. (1989) Am. J. Pathol. 134, 1201-1211.

21. Turrens, J. F., and McCord, J. M. (1988) 227, 43-46.
22. Aisen, P., Leibman, A., and Zweir, J. (1978) J. Biol. Chem. 253, 1930-1937.

23. Graham, G., and Bates, (1976) J. Lab. Clin. Med. 88, 477-486.

24. Bradford, M. (1976) Anal. Biochem. 72, 248-254.

25. Gotlib, L. J. (1982) Biochim. Biophys. Acta 685, 21-26.

26. Sun, I. L., Toole-Simms, W., Crane, F. L., Golub, E. S., Diaz de Pagan, T., Morre, D. J., and Low, H. (1987) Biochim. Biophys. Res. Commun. 146, 976-982.

27. Zweier, J. L., Kuppusamy, P., and Lutty, G. A. (1988) Proc. Natl. Acad. Sci. USA 85, 4046-4050.

28. Schafer, A. J., and Bunn, H. F. (1987) in Harrison's Principles of Internal Medicine (Isselhacher, K. J., Petersdarf, R. G., Wilson, J. D., Martin, J. B., and Fuaci, A. S., Eds.), p. 1494, McGraw-Hill, New York.

29. Freeman, B. A., Young, S. L., and Crapo, J. D. (1983) J. Biol. Chem. 256, 12534-12542.

30. Freeman, B. A., Topolosky, M. K., and Crapo, J. D. (1982) Arch. Biochem. Biophys. 216, 477-484.

31. Freeman, B. A., and Crapo, J. D. (1981) J. Biol. Chem. 256, 1098610992.

32. Turrens, J. F., Freeman, B. A., and Crapo, J. D. (1982) Arch. Biochem. Biophys. 217, 411-421.

33. Turrens, J. F., Freeman, B. A., Levitt, J. G. and Crapo, J. D. (1982) Arch. Biochem. Biophys. 217, 401-410.

34. Fridovich, I. (1970) J. Biol. Chem. 245, 4053-4057.

35. Heikkila, R. E., Cabbat, F. S., and Cohen, G. (1976) J. Biol. Chem. 251, 2182-2185.

36. Heikkila, R. E., Cabbat, F. S., and Cohen, G. (1978) Experientia 34, 1553-1554.

37. Heikkila, R. E. (1985) in Handbook of Methods for Oxygen Radical Research (Greenwald, Ed.), pp. 387-394, CRC Press, Boca Raton, FL.

38. Octave, J., Schneider, Y., Trouet, A., and Crichton, R. R. (1983) Trends Biochem. Sci., 8, 217-220.

39. Morgan, E., Huebers, H., and Finch, C. (1978) Blood 52, 1219 1228.

40. Lestas, A. (1976) Br. J. Haematol. 32, 341-350.

41. Schneider, Y. G., and Trouet, A. (1981) Eur. J. Biochem. 118, 3338.

42. Octave, J. N., Schneider, Y.-J., Hoffman, P., Trouet, A., and Crichton, R. R. (1979) FEBS Lett. 108, 127-130.

43. Ohkuma, S., and Poole, B. (1978) Proc. Natl. Acad. Sci. USA 75, 3327-3331.

44. Armstrong, N. J., and Morgan, E. H. (1983) Biochim. Biophys. Acta 762, 175-186.

45. Reijngoud, D. J., and Tager, J. M. (1976) FEBS Lett. 64, 231-235.

46. Baldwin, D. A., De Sousa, D. M., and Von Wandruszka, R. M. (1982) Biochim. Biophys. Acta 719, 140-146.

47. McGahan, M. C., and Fleisher, L. N. (1988) Graefe's Arch. Clin. Exp. Ophthalmol. 226, 27-30. 